\title{
Time-course analysis of counts and degranulation of mast cells during early intestinal ischemia-reperfusion injury in mice
}

\author{
MIAN GE*, XIAOLIANG GAN*, DEZHAO LIU, WENHUA ZHANG, \\ WANLING GAO, PINJIE HUANG and ZIQING HEI
}

Department of Anesthesiology, The Third Affiliated Hospital of Sun Yat-sen University, Guangzhou 510630, P.R. China

Received January 22, 2013; Accepted June 4, 2013

DOI: $10.3892 / \mathrm{mmr} .2013 .1530$

\begin{abstract}
Findings of previous studies have revealed that intestinal mucosal mast cells (IMMCs) are involved in small intestinal ischemia-reperfusion injury (IIRI). However, timecourse changes of mast cell counts and mast cell function in this process remain unclear. The present study aimed to observe the number of IMMCs and to investigate the correlation between their activation and small intestine injury at various time points during the period of small intestinal ischemia reperfusion (IIR). Healthy male Kunming mice were randomly divided into five groups, and were subjected to occlusion of the superior mesenteric artery (SMA) for $30 \mathrm{~min}$ and followed by reperfusion for 1, 3, 6 and $12 \mathrm{~h}$. By contrast, the SMA was isolated but not clamped in the baseline group. Chiu's scores were assessed by light microscopy, tryptase protein and MCP7 protein expression in the intestine were quantified, and mast cell counts and levels of histamine and TNF- $\alpha$ in the intestine were measured. The results showed that IIR induced severe intestine injury within $12 \mathrm{~h}$ as demonstrated by Chiu's scores that was greatly increased as compared to the baseline group, accompanied by increased mast cell counts, histamine and TNF- $\alpha$ levels. However, the Chiu's scores were reduced in the IIR $12 \mathrm{~h}$ group compared with the IIR $1 \mathrm{~h}$, IIR $3 \mathrm{~h}$ and IIR 6 h groups, with concomitant decreased mast cell counts, histamine and TNF- $\alpha$ levels. The tryptase and MCP7 protein expression was markedly increased in the IIR $1 \mathrm{~h}$ and IIR $3 \mathrm{~h}$ groups as compared with the baseline group, whereas this expression was gradually decreased at 6 and $12 \mathrm{~h}$ after reperfusion. The results of the present study suggest that IIR results in severe mucosal destruction within $6 \mathrm{~h}$ after reperfusion, associated with mast cell activation and substantial increases in the mast cell counts.
\end{abstract}

Correspondence to: Dr Ziqing Hei, Department of Anesthesiology, Third Affiliated Hospital of Sun Yat-sen University, Guangzhou 510630, P.R. China

E-mail: heiziqing@sina.com.cn

*Contributed equally

Key words: mast cell, intestine, ischemia reperfusion injury

\section{Introduction}

Intestinal ischemia-reperfusion injury (IIRI) plays a critical role in the pathophysiology of numerous conditions, including mesenteric arterial occlusion, shock, cardiopulmonary bypass, trauma, liver transplantation and small bowel transplantation. IIRI is one of the major causes leading to systemic inflammatory response syndrome (SIRS) and multiple organ failure (MOF), which are correlated with high mortality rates of $32.1-90 \%$ (1-4). A number of factors may contribute to IIRI and the mechanisms by which intestinal ischemia induces reperfusion injury are extremely complicated (5-7). Mast cells are widely distributed in intestinal mucosa and are known as intestinal mucosal mast cells (IMMCs). Andoh et al (8) used Ws/Ws rats to investigate the role of mucosal mast cells (MMCs) in the development of IIRI, and results of those authors revealed that the damage was greatly attenuated in mast cell-deficient rats. Kalia et al (9) also reported that ketotifen (mast cell stabilizer) inhibits ischemia-reperfusion-induced leukocyte adhesion and prevents local and remote organs from damage in rats subjected to intestinal ischemia-reperfusion (IIR). Moreover, results of our previous study (10) demonstrated that cromolyn sodium (mast cell stabilizer) and ketotifen markedly increase the survival rates at 3 days after IIR in rats, and also alleviate local and remote organ injury. The findings strongly suggest that mast cells play a key role in IIRI.

Previous studies $(10,11)$ have shown that IIR leads to changes in IMMC counts. Boros et al (11) investigated the changes of intestinal mast cells in rats following 15,30 , or $60 \mathrm{~min}$ ischemia and $30 \mathrm{~min}$ reperfusion, respectively, and the results clearly showed that mast cell counts are in part implicated in the severity of intestinal injury. However, those studies $(10,11)$ only focused on one end point in rats subjected to small intestinal ischemia, and the changes of IMMC counts and their function at various time points during reperfusion after intestinal ischemia are poorly understood. Furthermore, the correlation between IIRI and mast cell counts is also not well documented. It is well known that the histological changes of the intestine induced by IIRI begin to recover at $6 \mathrm{~h}$ after reperfusion in rats subjected to $60 \mathrm{~min}$ ischemia that were suffering from severe damage at $3 \mathrm{~h}(12,13)$. Nevertheless, those studies did not investigate the changes of mast cell counts and mast cell activation in the process of IIRI. Therefore, it is imperative to elucidate the correlations and changes in mast 
cell counts and activation and intestinal injury in order to improve treatment of IIRI. In the present study, we observed the number and activation of IMMCs within $12 \mathrm{~h}$ of IIR.

\section{Materials and methods}

Animals and experimental groups. Thirty-five male Kunming mice weighing 18-24 g (provided by Experimental Animal Center of Guangdong Province, China) were used in this study. The experiments were approved by the Institutional Animal Care and Use Committee of Sun Yat-Sen University. The animals were housed with standard chow and free access to water and were subjected to a 12-h light-dark cycle (8:00 a.m.-8:00 p.m. light). Mice were randomly divided into five groups: baseline, IIR $1 \mathrm{~h}$ (intestinal ischemia for $30 \mathrm{~min}$ followed by $1 \mathrm{~h}$ reperfusion), IIR $3 \mathrm{~h}$ (intestinal ischemia for $30 \mathrm{~min}$ followed by $3 \mathrm{~h}$ reperfusion), IIR $6 \mathrm{~h}$ (intestinal ischemia for $30 \mathrm{~min}$ followed by $6 \mathrm{~h}$ reperfusion) and IIR $12 \mathrm{~h}$ (intestinal ischemia for $30 \mathrm{~min}$ followed by $12 \mathrm{~h}$ reperfusion) groups.

Experimental model of IRRI. Mice were fasted for $12 \mathrm{~h}$ and were anesthetized by an intraperitoneal injection of $10 \%$ chloral hydrate $(3.5 \mathrm{ml} / \mathrm{kg})$. Following anesthesia, the mice were fixed in a supine position, the abdomen was incised and the superior mesenteric artery (SMA) was confirmed and isolated. Mice in the IIR 1, 3, 6 and $12 \mathrm{~h}$ groups suffered ischemia by occlusion of the SMA for $30 \mathrm{~min}$ and then the clamp was released and the mice were maintained for $1,3,6$ and $12 \mathrm{~h}$, respectively. In the baseline group, the same surgery was performed, with the exception of the clamping of the SMA, and the animals were maintained for $1 \mathrm{~h}$. The mice were injected subcutaneously with $0.1 \mathrm{ml}$ physiological saline after the clamp was released. Following completion of the experiments, the mice were sacrificed and the intestinal tissues were obtained for further study. The animals were maintained at $37^{\circ} \mathrm{C}$ by using a warm pad during the procedure.

Histopathological examination of intestine. A segment of $1.0 \mathrm{~cm}$ intestine (from $5 \mathrm{~cm}$ of the terminal ileum) was harvested and fixed in $10 \%$ formaldehyde. The small intestine tissues were paraffin-embedded and then stained with hematoxylin and eosin for light microscopy. Intestinal mucosal damage was evaluated by two pathologists, who were blinded initially to the experiment, using the criteria of Chiu's method (14) as follows: Grade 0, normal mucosa villi; Grade 1, development of subepithelial Gruenhagen's space at the tip of villus; Grade 2, extension of the subepithelial space with moderate epithelial lifting; Grade 3, large epithelial lifting, possibly with a few denuded villi; Grade 4, denuded villi with lamina propria and exposed capillaries; Grade 5, disintegration of the lamina propria, ulceration and hemorrhage.

Immunohistochemical detection of tryptase in intestine and IMMC counts. Sections $(5 \mu \mathrm{m})$ of small intestine were prepared from paraffin-embedded tissue according to previous instructions $(9,10)$, with minor revisions. Briefly, endogenous peroxidase was quenched with $3 \% \mathrm{H}_{2} \mathrm{O}_{2}$ in deionized water for $10 \mathrm{~min}$ after deparaffinization. Non-specific binding sites were blocked by incubating the sections in $10 \%$ normal rabbit serum for $1 \mathrm{~h}$. The sections were then incubated with polyclonal rat anti-mast cell tryptase (dilution 1:2,000) at $37^{\circ} \mathrm{C}$ for $20 \mathrm{~min}$, followed by incubation with biotinylated mouse-anti-rat IgG for $10-15 \mathrm{~min}$ at room temperature. The horseradish peroxidase-conjugated streptavidin solution was added and incubated for 10-15 $\mathrm{min}$ at room temperature after three 5 min PBS rinses. The antibody binding sites were visualized by incubation with a diaminobenzidine $-\mathrm{H}_{2} \mathrm{O}_{2}$ solution . Sections incubated with PBS instead of the primary antibody were used as negative controls. Brown-yellow granules in the cytoplasm were identified as positive staining for tryptase. The counts of tryptase-positive mast cells were calculated in five randomly selected areas by Image-Pro Plus 5.0 (Media Cybernetics, Inc., Rockville, MD, USA) software at a x400 magnification (15).

Western blot analysis of intestinal MCP7. Total proteins were extracted from frozen intestine tissues using protein extraction kits for MCP7 measurement (KenGen Biotech Company, Nanjing, China). Protein concentration was measured by BCA Protein Assay reagent kit (KenGen Biotech Company). Protein $(60 \mu \mathrm{g})$ was loaded onto a 4-20\% SDS-PAGE premade gel (Invitrogen, Carlsbad, CA, USA) for polyacrylamide gel electrophoresis and then transferred to a polyvinylidene fluoride (PVDF) membrane pretreated with $100 \%$ methanol. Membranes loaded with proteins of interest were incubated with 5\% skimmed milk, and then rat monoclonal anti-MCP7 antibody (1:500 dilution, Santa Cruz, USA) was added to the supernatant and the mixture was incubated on a rotating wheel at $4^{\circ} \mathrm{C}$ overnight. On the second day, membranes were washed with TBST three times and incubated with a second antibody conjugated to horseradish peroxidase (1:2,000 dilution, Santa Cruz Biotechnology, Santa Cruz, CA, USA) for $1 \mathrm{~h}$ at room temperature. Immunoblots were washed and then were incubated with an enhanced chemiluminescence detection system (KeyGen Biotech). After exposure to hyperfilm-ECL, the membranes were stripped and reprobed with $\beta$-actin antibody (1:2,000 dilution, Santa Cruz Biotechnology). Densitometry was analyzed using NIH ImageJ software (http://rsb.info.nih. gov/ij/index.html) and normalized by $\beta$-actin immunoreactivity to correct sample differences (16).

Detection of histamine and TNF- $\alpha$ levels in intestine. The other segment of intestine tissue was homogenized with frozen normal saline, then centrifuged at $1,500 \mathrm{x}$ g for $15 \mathrm{~min}$. Supernatants were transferred into fresh tubes for detection of histamine and TNF- $\alpha$. Intestinal protein was determined using a BCA Protein Assay Kit (KenGen Biotech Company). The concentrations of histamine and TNF- $\alpha$ were measured using an enzymelinked immunosorbent assay (ELISA) kit (R\&D systems Inc., Minneapolis, MN, USA). The absorbance was read at $450 \mathrm{~nm}$ by a Biokinetics microplate reader Model EL340 (Biotek Instruments, Anaheim, CA, USA). The histamine and TNF- $\alpha$ levels were expressed as $\mathrm{ng} / \mathrm{ml}$ and $\mathrm{pg} / \mathrm{ml}$, respectively. The concentrations of histamine and TNF- $\alpha$ in the intestine were calculated as $\mathrm{ng} / \mathrm{mg}$ protein and $\mathrm{pg} / \mathrm{mg}$ protein, respectively.

Statistical analysis. Data were expressed as the means \pm SD, and were analyzed using SPSS 12.0 software (SPSS Inc., Chicago, IL, USA). Repeated measurements were used for 


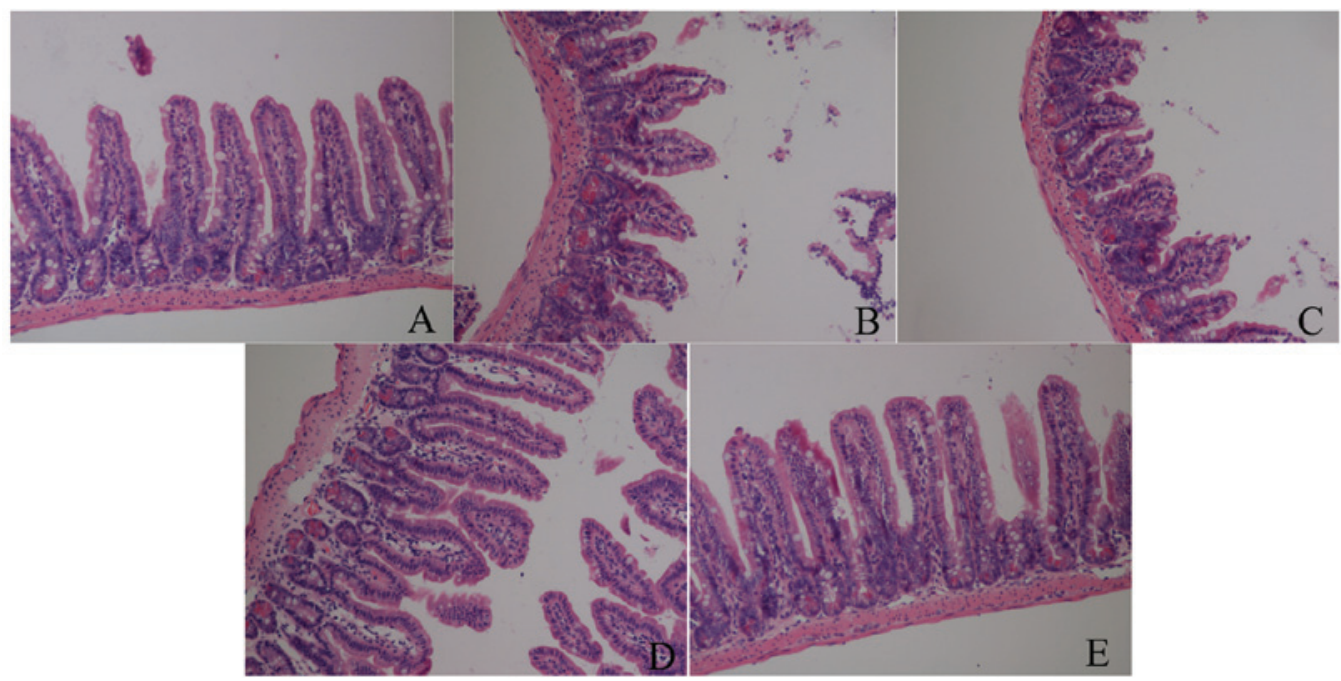

Figure 1. Histological analysis of small intestinal mucosa after H\&E staining (x200). (A-E) Representative images of the baseline; $1 \mathrm{~h}$ after reperfusion (IIR 1H), $3 \mathrm{~h}$ after reperfusion (IIR 3H), $6 \mathrm{~h}$ after reperfusion (IIR 6H) and $12 \mathrm{~h}$ after reperfusion (IIR 12H) groups. H\&E, hematoxylin and eosin.

intra-group comparison. $\mathrm{P}<0.05$ was considered to indicate a statistically significant difference.

\section{Results}

Changes of intestinal mucosa under light microscopy and Chiu's scores. As shown in Fig. 1, there was no damage in the baseline group, which showed normal villus and glands. However, IIR induced intestinal structural destruction, particularly at $3 \mathrm{~h}$ after reperfusion, in which all the animals showed massive epithelial lifting down the sides of the villi, accompanied with some denuded villi and lamina propria in the IIR $1 \mathrm{~h}$, IIR $3 \mathrm{~h}$ and IIR $6 \mathrm{~h}$ groups. Furthermore, the most severe injury was assessed in the IIR $3 \mathrm{~h}$ group, in which disintegration of the lamina propria and hemorrhage was observed. Nevertheless, there was less damage in the IIR $12 \mathrm{~h}$ group, which showed only an extension of the subepithelial space with lifting of the epithelial layer in the intestine.

IIR led to marked increases in the Chiu's scores $12 \mathrm{~h}$ after the clamp was released as compared with the baseline group (all $\mathrm{P}<0.05$ vs. baseline group). As shown in Fig. 2, the Chiu's scores peaked at $3 \mathrm{~h}$ after reperfusion and then decreased gradually, and the Chiu's scores were markedly lowered at $12 \mathrm{~h}$ after reperfusion as compared with the IIR $1 \mathrm{~h}$, IIR $3 \mathrm{~h}$ and IIR 6 h groups $(\mathrm{P}<0.05)$.

Immunohistochemical detection of tryptase and IMMC counts in the intestine. IIR induced the IMMC counts to increase significantly up to $6 \mathrm{~h}$ after reperfusion, particularly at $1 \mathrm{~h}$, compared with the baseline group, and the counts were slightly decreased by $6 \mathrm{~h}$ after reperfusion. The counts in the IIR $1 \mathrm{~h}$, IIR $3 \mathrm{~h}$ and IIR $6 \mathrm{~h}$ groups were comparable, while the counts were decreased to the baseline level at $12 \mathrm{~h}$ after reperfusion in the IIR $12 \mathrm{~h}$ group (Fig. 3).

Consistent with the IMMC counts, the tryptase protein expression in the IIR $1 \mathrm{~h}$ group was higher than that in the baseline group, and was slightly but not significantly decreased in the IIR $3 \mathrm{~h}$ and IIR $6 \mathrm{~h}$ groups. Furthermore, the tryptase

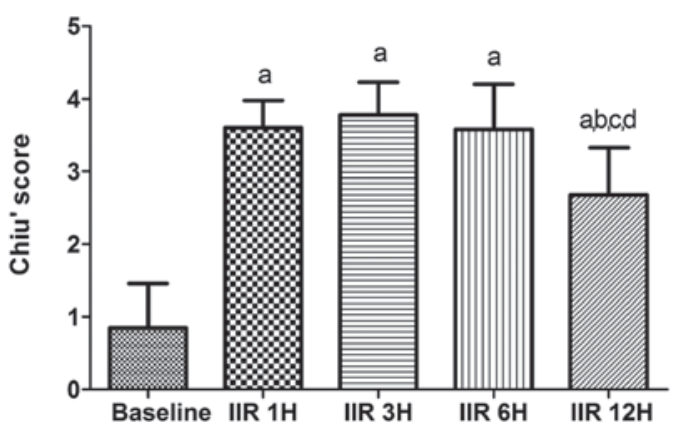

Figure 2. Changes of Chiu's score in the intestine. Baseline, baseline group; IIR $1 \mathrm{H}, 1 \mathrm{~h}$ after reperfusion; IIR $3 \mathrm{H}, 3 \mathrm{~h}$ after reperfusion; IIR $6 \mathrm{H}, 6 \mathrm{~h}$ after reperfusion; IIR $12 \mathrm{H}, 12 \mathrm{~h}$ after reperfusion. Results are expressed as the means $\pm \mathrm{SD}$ ( $\mathrm{n}=7$ per group). ${ }^{\mathrm{a}} \mathrm{P}<0.05$, compared with baseline group; ${ }^{\mathrm{b}} \mathrm{P}<0.05$, compared with IIR $1 \mathrm{H}$ group; ${ }^{\mathrm{C}} \mathrm{P}<0.05$, compared with IIR $3 \mathrm{H}$ group; ${ }^{\mathrm{P}}<0.05$, compared with IIR $6 \mathrm{H}$ group.

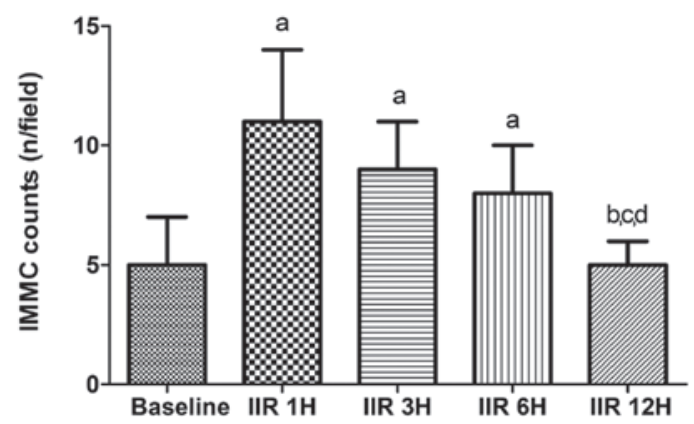

Figure 3. Changes of IMMC counts in the intestine. Baseline, baseline group; IIR $1 \mathrm{H}, 1 \mathrm{~h}$ after reperfusion; IIR $3 \mathrm{H}, 3 \mathrm{~h}$ after reperfusion; IIR $6 \mathrm{H}, 6 \mathrm{~h}$ after reperfusion; IIR $12 \mathrm{H}, 12 \mathrm{~h}$ after reperfusion. Results are expressed as the means \pm S.D. $n=7$ per group. ${ }^{\text {a }} \mathrm{P}<0.05$, compared with baseline group; ${ }^{\mathrm{b}} \mathrm{P}<0.05$, compared with IIR $1 \mathrm{H}$ group; ${ }^{\mathrm{c}} \mathrm{P}<0.05$, compared with IIR $3 \mathrm{H}$ group; ${ }^{\mathrm{P}}<0.05$, compared with IIR $6 \mathrm{H}$ group.

protein expression in the IIR $12 \mathrm{~h}$ group was markedly reduced compared with the IIR $1 \mathrm{~h}$, IIR $3 \mathrm{~h}$ and IIR $6 \mathrm{~h}$ groups, and was decreased to baseline levels (Figs. 4 and 5). 


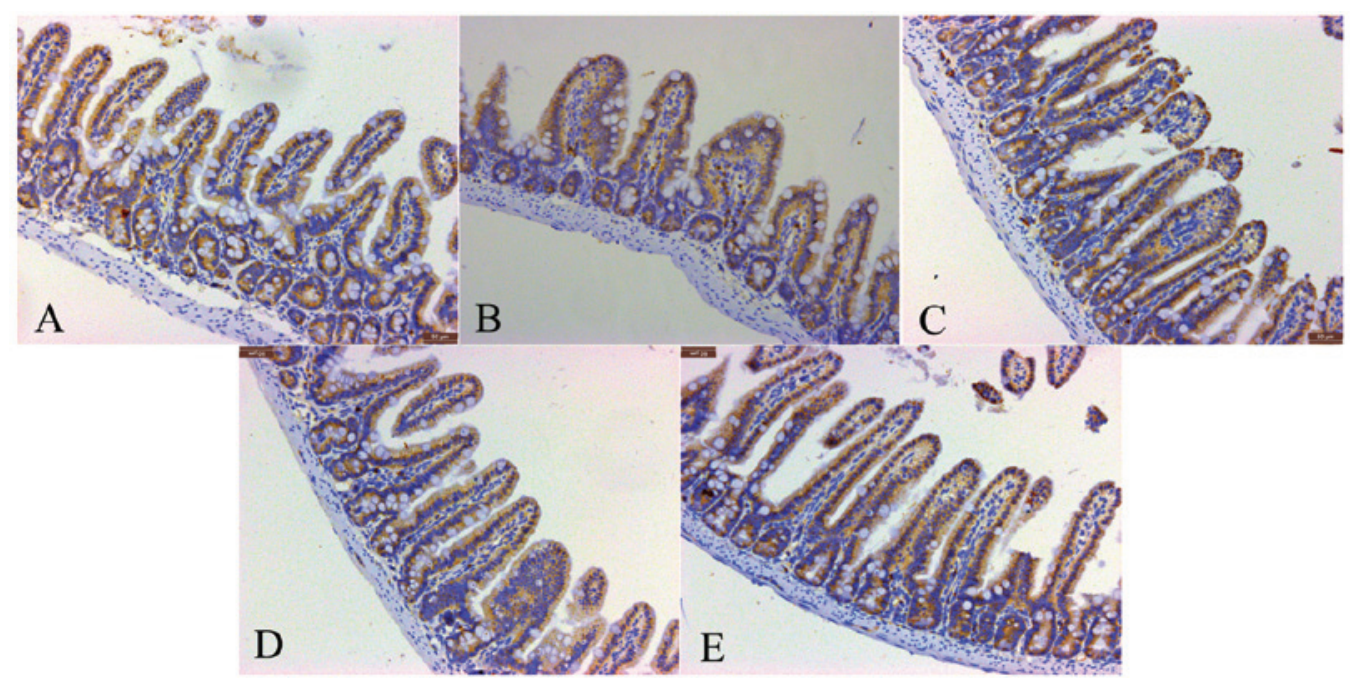

Figure 4. Immunohistochemical detection of tryptase in small intestine (magnification, x200). (A-E) Representative images of the baseline $1 \mathrm{~h}$ after reperfusion (IIR $1 \mathrm{H}$ ), $3 \mathrm{~h}$ after reperfusion (IIR 3H), $6 \mathrm{~h}$ after reperfusion (IIR 6H) and $12 \mathrm{~h}$ after reperfusion (IIR 12H) groups.

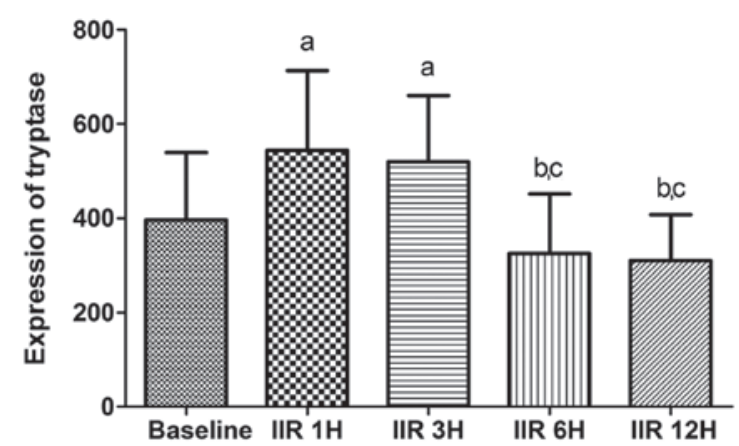

Figure 5. Changes of expression of tryptase in the intestine. Baseline, baseline group; IIR $1 \mathrm{H}, 1 \mathrm{~h}$ after reperfusion; IIR $3 \mathrm{H}, 3 \mathrm{~h}$ after reperfusion; IIR $6 \mathrm{H}, 6 \mathrm{~h}$ after reperfusion; and IIR $12 \mathrm{H}, 12 \mathrm{~h}$ after reperfusion. Results are expressed as the means $\pm \mathrm{SD}$ ( $\mathrm{n}=7$ per group). ${ }^{\mathrm{a}} \mathrm{P}<0.05$, compared with the baseline group; ${ }^{\mathrm{b}} \mathrm{P}<0.05$, compared with the IIR $1 \mathrm{H}$ group; ${ }^{\mathrm{C}} \mathrm{P}<0.05$, compared with IIR $3 \mathrm{H}$ group.

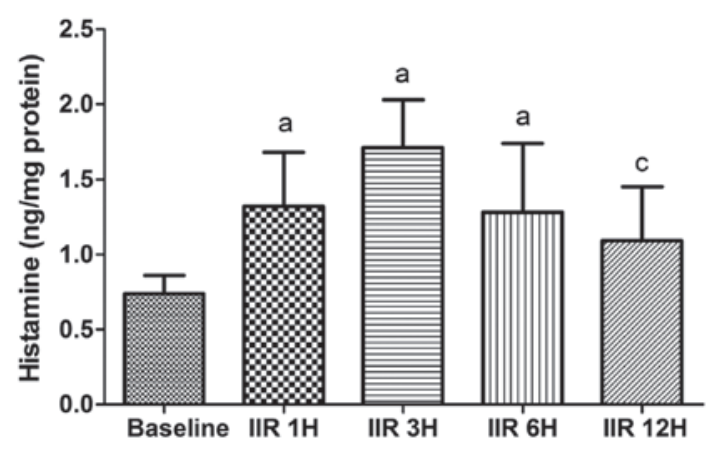

Figure 6. Changes of histamine concentration in the intestine. Baseline, baseline group; IIR $1 \mathrm{H}, 1 \mathrm{~h}$ after reperfusion; IIR $3 \mathrm{H}, 3 \mathrm{~h}$ after reperfusion; IIR $6 \mathrm{H}, 6 \mathrm{~h}$ after reperfusion; IIR $12 \mathrm{H}, 12 \mathrm{~h}$ after reperfusion. Results are expressed as the means $\pm \mathrm{SD}$ ( $\mathrm{n}=7$ per group). ${ }^{\mathrm{a}} \mathrm{P}<0.05$, compared with the baseline group; ${ }^{\mathrm{P}} \mathrm{P}<0.05$, compared with the IIR $3 \mathrm{H}$ group.

Histamine contents in the small intestine. Compared with the baseline group, the histamine contents in the small intestine were significantly higher in the IIR $1 \mathrm{~h}$, IIR $3 \mathrm{~h}$ and IIR $6 \mathrm{~h}$

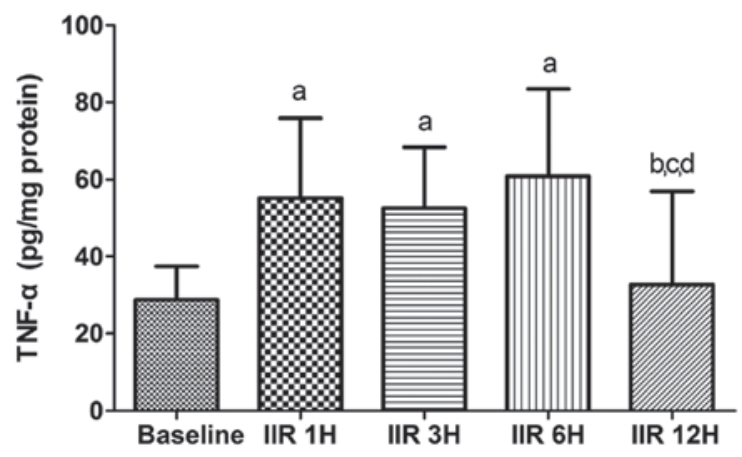

Figure 7. Changes of TNF- $\alpha$ in the intestine. Baseline, baseline group; IIR $1 \mathrm{H}, 1 \mathrm{~h}$ after reperfusion; IIR $3 \mathrm{H}, 3 \mathrm{~h}$ after reperfusion; IIR $6 \mathrm{H}, 6 \mathrm{~h}$ after reperfusion; IIR $12 \mathrm{H}, 12 \mathrm{~h}$ after reperfusion. Results are expressed as the means $\pm \mathrm{SD}$ ( $\mathrm{n}=7$ per group). ${ }^{\mathrm{a}} \mathrm{P}<0.05$, compared with the baseline group; ${ }^{\mathrm{b}} \mathrm{P}<0.05$, compared with the IIR $1 \mathrm{H}$ group; ${ }^{\mathrm{c}} \mathrm{P}<0.05$, compared with the IIR $3 \mathrm{H}$ group; ${ }^{\mathrm{d}} \mathrm{P}<0.05$, compared with the IIR $6 \mathrm{H}$ group.

groups $(\mathrm{P}<0.05)$. Moreover, the histamine contents reached a maximum level at $3 \mathrm{~h}$ after reperfusion, as shown in Fig. 5, but this level was not significantly increased as compared with the IIR $1 \mathrm{~h}$ and IIR $6 \mathrm{~h}$ groups. The histamine content in the IIR $12 \mathrm{~h}$ group was significantly lower than that in the IIR $3 \mathrm{~h}$ group ( $\mathrm{P}<0.05$; Fig. 6$)$.

TNF- $\alpha$ levels in small intestine. As shown in Fig. 6, IIR-induced TNF- $\alpha$ levels markedly increased in the IIR $1 \mathrm{~h}$, IIR $3 \mathrm{~h}$ and IIR $6 \mathrm{~h}$ groups as compared with the baseline group $(\mathrm{P}<0.05)$. After reaching a plateau level, the contents of TNF- $\alpha$ in the intestine were markedly decreased to the baseline level (Fig. 7).

Expression of MCP7 in intestine. MCP7 is a subtype of tryptase. As shown in Fig. 7, the expression of MCP7 was gradually increased in the $6 \mathrm{~h}$ following the clamp release, and reached maximum levels in the IIR $3 \mathrm{~h}$ and IIR $6 \mathrm{~h}$ groups as compared to the baseline group. Notably, the expression of MCP7 was markedly decreased to baseline levels at $12 \mathrm{~h}$ after reperfusion (Fig. 8). 

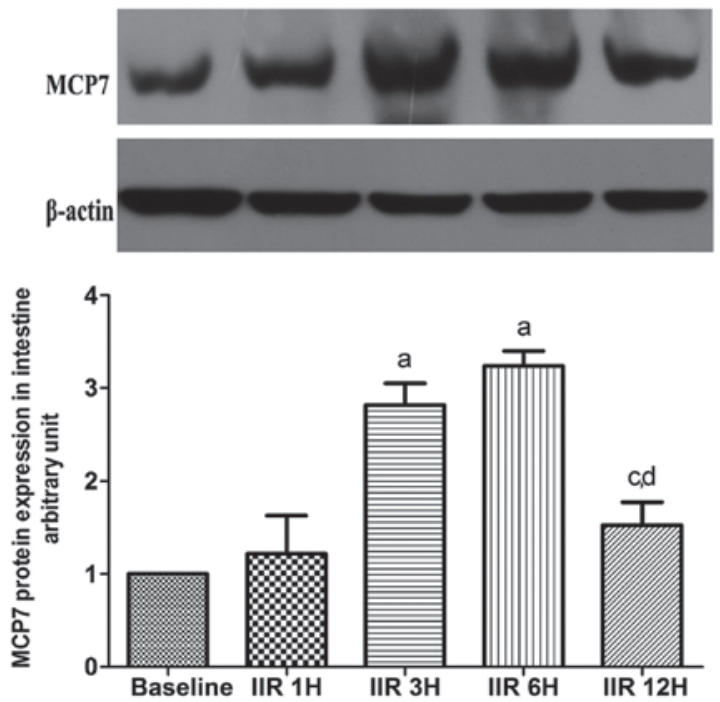

Figure 8. Western blot analysis of expression of small intestine MCP7 (means $\pm \mathrm{SD}, \mathrm{n}=7$ ). Baseline, baseline group; IIR $1 \mathrm{H}, 1 \mathrm{~h}$ after reperfusion; IIR $3 \mathrm{H}, 3 \mathrm{~h}$ after reperfusion; IIR $6 \mathrm{H}, 6 \mathrm{~h}$ after reperfusion; IIR $12 \mathrm{H}, 12 \mathrm{~h}$ after reperfusion. ${ }^{\mathrm{a}} \mathrm{P}<0.05$, compared with the baseline group; ${ }^{\mathrm{b}} \mathrm{P}<0.05$, compared with the IIR $1 \mathrm{H}$ group; ${ }^{\mathrm{C}} \mathrm{P}<0.05$, compared with the IIR $3 \mathrm{H}$ group; ${ }^{\mathrm{d}} \mathrm{P}<0.05$, compared with IIR $6 \mathrm{H}$ group.

\section{Discussion}

The damage to small intestinal mucosa and the recovery after IIR depend on the duration of ischemia and the animal species involved. In the present study, we observed that IIR led to the greatest destruction of pathological structure at $6 \mathrm{~h}$ after reperfusion. As shown in Fig. 1, massive collapsed epithelia and villi, as well as denuded villi and lamina propria were observed, and the structure of intestinal mucosa, as assessed by light microscopy, appeared to recover to normal at $12 \mathrm{~h}$ after release of the clamp, which is in agreement with the study of Chang et al (12), in which they reported that the small intestinal mucosal injury in rats that were subjected to $60 \mathrm{~min}$ of hemorrhagic shock was severe at the onset after resuscitation, and the structure of small intestinal mucosa began to recover gradually at $6 \mathrm{~h}$ after resuscitation and almost normal intestinal mucosa was observed at $24 \mathrm{~h}$ after reperfusion.

IMMCs, widely distributed in the intestinal lamina propria, are adjacent to blood vessel and nerve fiber cells. IMMCs interact with neuropeptides and cytokines through the immune and neural pathways, which play an important role in regulating the physical function of the gastrointestinal tract, as well as the development of inflammatory bowel diseases $(17,18)$. A study has previously demonstrated that the ratio of IMMCs to intestinal mucosal lamina propria cells is $\sim 2-3 \%$ under normal conditions. However, this ratio can increase by 10 -fold in subjects suffering from intestinal diseases (19). Several lines of evidence have demonstrated that mast cells play a critical role in small IIRI by using mast cell-deficient rats or by inhibiting mast cells (8-10).

Mast cells are important pro-inflammatory cells. Previous studies $(20,21)$ have reported that the number of mast cells were increased in lungs, intestines or other organs subjected to ischemia-reperfusion injury. In the present study, the find- ings showed that 30 min of ischemia followed by 1,3 or $6 \mathrm{~h}$ of reperfusion induced a significant increase in the number of IMMCs by analyzing time-course changes of mast cell counts. Moreover, the IMMC counts were higher at $1 \mathrm{~h}$ after reperfusion, and then the IMMC counts gradually decreased to baseline at $12 \mathrm{~h}$ after reperfusion, which is consistent with the Chiu's scores, although severe intestinal mucosal destruction was found at $6 \mathrm{~h}$ after initiation of reperfusion.

Mast cells are generated in the bone marrow, and then distributed to tissues and organs, and play various roles in regulating physiological function (22). A previous study (23) has reported that bone marrow-derived mast cells (BMMCs) migrate to the injury sites to serve their function. MCP7 is a subtype of tryptase and is only expressed in immature BMMCs (24). Accordingly, the expression of MCP7 can partly identify the number of BMMCs that have migrated to injured tissues (25). The findings in the present study have shown that the MCP7 expression was substantially increased at $3 \mathrm{~h}$ after reperfusion, slowly decreased at $6 \mathrm{~h}$ and had almost reached baseline level at $12 \mathrm{~h}$ after reperfusion. The findings suggest that small intestinal ischemia-reperfusion may result in BMMC migration to the injured intestine tissue, which further aggravates small intestine injury by releasing numerous chemokines and cytokines.

Levels of histamine and tryptase are characteristic markers of mast cell activation and degranulation. Previous studies $(26,27)$ have demonstrated that histamine and tryptase, which are involved in tissue injury, was able to increase microvascular permeability, induce inflammatory cell infiltration, and amplify the effects of mast cells. Several studies $(9,10,28)$ have confirmed that the application of mast cell membrane stabilizers or antihistamines were capable of inhibiting mast cell degranulation and attenuate IIRI. In the present study, we observed that the levels of histamine and tryptase in the small intestine were markedly and rapidly increased after IIR, and peaked within $3 \mathrm{~h}$ after reperfusion, and then gradually decreased to the baseline level at $12 \mathrm{~h}$. Furthermore, these changes were consistent with the pathological damage. The results indicated that the best time to target mast cells is at $\sim 3 \mathrm{~h}$ after reperfusion.

Inflammatory reactions mediated by cytokines are one of the main mechanisms of IIRI. Among the many mediators that contribute to IIR, TNF- $\alpha$ is one of the key mediators and initiates the cascade effect (29). A number of cells, such as endothelial cells as well as inflammatory cells, are capable of producing TNF- $\alpha$ when they are subjected to injury. Mast cells can also produce and release TNF- $\alpha$. Furthermore, Bischoff et al (30) speculated that the concentration of TNF- $\alpha$ in the small intestine is largely from IMMC degranulation. The findings in the present study showed that the levels of TNF- $\alpha$ in intestine were greatly increased at $6 \mathrm{~h}$ after reperfusion, and then decreased gradually at $12 \mathrm{~h}$ after reperfusion. Of note, the results were in agreement with the changes of mast cell counts and intestinal injury scores. Therefore, the results suggest that mast cell degranulation leads to small intestinal ischemia reperfusion injury.

In conclusion, small intestinal ischemia reperfusion results in substantial increases in the mast cell counts within $6 \mathrm{~h}$ after reperfusion, which contributes to the small intestine mucosal destruction by degranulation. 


\section{Acknowledgements}

The study was in part supported by the National Natural Science Foundation of China (NSFC), 30901408 and 30972858.

\section{References}

1. Schoots IG, Koffeman GI, Legemate DA, Levi $M$ and van Gulik TM: Systematic review of survival after acute mesenteric ischaemia according to disease aetiology. Br J Surg 91: 17-27, 2004.

2. Acosta-Merida MA, Marchena-Gomez J, HemmersbachMiller M, Roque-Castellano C and Hernandez-Romero JM: Identification of risk factors for perioperative mortality in acute mesenteric ischemia. World J Surg 30: 1579-1585, 2006.

3. Pierro A and Eaton S: Intestinal ischemia reperfusion injury and multisystem organ failure. Semin Pediatr Surg 13: 11-17, 2004.

4. Kassahun WT, Schulz T, Richter O and Hauss J: Unchanged high mortality rates from acute occlusive intestinal ischemia: six year review. Langenbecks Arch Surg 393: 163-171, 2008.

5. Cerqueira NF, Hussni CA and Yoshida WB: Pathophysiology of mesenteric ischemia/reperfusion: a review. Acta Cir Bras 20: 336-343, 2005

6. Haddad JJ: Antioxidant and prooxidant mechanisms in the regulation of redox $(\mathrm{y})$-sensitive transcription factors. Cell Signal 14 879-897, 2002.

7. Vollmar B and Menger MD: Intestinal ischemia/reperfusion: microcirculatory pathology and functional consequences Langenbecks Arch Surg 396: 13-29, 2011

8. Andoh A, Kimura T, Fukuda M, Araki Y, Fujiyama Y and Bamba T: Rapid intestinal ischaemia-reperfusion injury is suppressed in genetically mast cell-deficient Ws/Ws rats. Clin Exp Immunol 116: 90-93, 1999.

9. Kalia N, Brown NJ, Wood RF and Pockley AG: Ketotifen abrogates local and systemic consequences of rat intestinal ischemia-reperfusion injury. J Gastroenterol Hepatol 20: 1032-1038, 2005.

10. Hei ZQ, Gan XL, Huang PJ, Wei J, Shen N and Gao WL: Influence of ketotifen, cromolyn sodium, and compound 48/80 on the survival rates after intestinal ischemia reperfusion injury in rats. BMC Gastroenterol 8: 42, 2008.

11. Boros M, Takaichi S, Masuda J, Newlands GF and Hatanaka K: Response of mucosal mast cells to intestinal ischemia-reperfusion injury in the rat. Shock 3: 125-131, 1995.

12. Chang JX, Chen S, Ma LP, et al: Functional and morphological changes of the gut barrier during the restitution process after hemorrhagic shock. World J Gastroenterol 11: 5485-5491, 2005.

13. Noda T, Iwakiri R, Fujimoto $K$, Matsuo $S$ and Aw TY: Programmed cell death induced by Ischemia-reperfusion in rat intestinal mucosa. Am J Physiol 274 (2 Pt 1): G270-G276, 1998.

14. Chiu CJ, Mcardle AH, Brown R, Scott HJ and Gurd FN: Intestinal mucosal lesion in low flow states. Arch Surg 101: 478-483, 1970 .
15. Thakurdas SM, Melicoff E, Sanscores-Garcia L, Moreira DC, Petrova Y, Stevens RL and Adachi R: The mast cell-restricted tryptase mMCP-6 has a critical immunoprotective role in bacterial infections. J Biol Chem 282: 20809-20815, 2007.

16. Kemna E, Pickkers P, Nemeth E, van der Hoeven $H$ and Swinkels D: Time-course analysis of hepcidin, serum iron, and plasma cytokine levels in humans injected with LPS. Blood 106: 1864-1866, 2005.

17. Bischoff SC: Physiological and pathophysiological functions of intestinal mast cells. Semin Immunopathol 31: 185-205, 2009.

18. Wierzbicki M and Brzezińska-Błaszczyk E: The role of mast cells in the development of inflammatory bowel diseases. Postepy Hig Med Dosw (Online) 62: 642-650, 2008.

19. Bischoff SC and Kramer S: Human mast cells, bacteria, and intestinal immunity. Immunol Rev 217: 329-337, 2007.

20. Hei ZQ, Gan XL, Luo GJ, Li SR and Cai J: Pretreatment of cromolyn sodium prior to reperfusion attenuates early reperfusion injury after the small intestine ischemia in rats. World $\mathrm{J}$ Gastroenterol 13: 5139-5146, 2007.

21. Lindsberg PJ, Strbian D and Karjalainen-Lindsberg ML: Mast cells as early responders in the regulation of acute blood-brain barrier changes after cerebral ischemia and hemorrhage. J Cereb Blood Flow Metab 30: 689-702, 2010.

22. Morii E: Development of mast cells: analysis with mutant mice. Int J Hematol 86: 22-26, 2007.

23. Okayama Y and Kawakami T: Development, migration, and survival of mast cells. Immunol Res 34: 97-115, 2006.

24. McNeil HP, Reynolds DS, Schiller V, et al: Isolation, characterization, and transcription of the gene encoding mouse mast cell protease 7. Proc Natl Acad Sci USA 89: 11174-11178, 1992.

25. Funaba M, Ikeda T, Murakami M, et al: Transcriptional activation of mouse mast cell protease-7 by activin and transforming growth factor-beta is inhibited by microphthalmia-associated transcription factor. J Biol Chem 278: 52032-52041, 2003.

26. Caughey GH: Mast cell tryptases and chymases in inflammation and host defense. Immunol Rev 217:141-154, 2007.

27. He S, Gaca MD and Walls AF: A role for tryptase in the activation of human mast cells: modulation of histamine release by tryptase and inhibitors of tryptase. J Pharmacol Exp Ther 286: 289-297, 1998

28. Gan XL, Hei ZQ, Huang HQ, Chen LX, Li SR and Cai J: Effect of Astragalus membranaceus injection on the activity of the intestinal muscosal mast cells after hemorrhagic shockreperfusion in rats. Chin Med J 119: 1892-1898, 2006.

29. Pascher A and Klupp J: Biologics in the treatment of transplant rejection and ischemia/reperfusion injury: new applications for TNFalpha inhibitors? BioDrugs 19: 211-231, 2005.

30. Bischoff SC, Lorentz A, Schwengberg S, Weier G, Raab R and Manns MP: Mast cells are an important cellular source of tumour necrosis factor alpha in human intestinal tissue. Gut 44: 643-652, 1999. 